\title{
Differences that matter: hiring modes and demographic (dis)similarity in executive selection
}

Article

Accepted Version

Georgakakis, D., Greve, P. ORCID: https://orcid.org/00000002-2936-4399 and Ruigrok, W. (2021) Differences that matter: hiring modes and demographic (dis)similarity in executive selection. The International Journal of Human Resource Management, 32 (3). pp. 650-679. ISSN 1466-4399 doi: https://doi.org/10.1080/09585192.2018.1496126 Available at https://centaur.reading.ac.uk/78123/

It is advisable to refer to the publisher's version if you intend to cite from the work. See Guidance on citing.

To link to this article DOI: http://dx.doi.org/10.1080/09585192.2018.1496126

Publisher: Taylor \& Francis

All outputs in CentAUR are protected by Intellectual Property Rights law, including copyright law. Copyright and IPR is retained by the creators or other copyright holders. Terms and conditions for use of this material are defined in the End User Agreement. 


\section{CentAUR}

Central Archive at the University of Reading

Reading's research outputs online 
DIFFERENCES THAT MATTER: HIRING MODES AND DEMOGRAPHIC

(DIS)SIMILARITY IN EXECUTIVE SELECTION

\author{
Dimitrios Georgakakis ${ }^{\text {a }}$ \\ e-mail: dimitrios.georgakakis@unisg.ch \\ Peder Greve ${ }^{b *}$ \\ e-mail: peder.greve@henley.ac.uk \\ Winfried Ruigrok ${ }^{a}$ \\ e-mail: winfried.ruigrok@unisg.ch \\ ${ }^{a}$ University of St. Gallen \\ Research Institute for International Management \\ Dufourstrasse 40a \\ CH-9000 St. Gallen, Switzerland \\ Tel: (+41)-71-2242448 \\ Fax: (+41)-71-2242447 \\ ${ }^{\mathrm{b}}$ Henley Business School, University of Reading \\ International Business and Strategy \\ Henley-on-Thames, Oxon, RG9 3AU, UK \\ Tel: (+44)-1491-414-522 \\ * Corresponding author
}

- Accepted for publication in The International Journal of Human Resource Management - 


\title{
DIFFERENCES THAT MATTER: HIRING MODES AND DEMOGRAPHIC (DIS)SIMILARITY IN EXECUTIVE SELECTION
}

\begin{abstract}
Scholars, practitioners, and policymakers have long acknowledged the importance of understanding the antecedents of top management team (TMT) composition. Yet, research on how and why firms select executives who are demographically dissimilar to incumbent TMT members remains limited. We take a step toward answering these questions by employing a sample of 575 individual-level executive appointments at 170 large European firms between 2005 and 2009. Drawing on the person-group fit perspective, we argue that firms are more likely to appoint sociodemographically dissimilar executives through internal promotion - while external hires are more likely to socio-demographically resemble incumbent top managers. Our results support the hypothesized relationship. They also show that this relationship is influenced by the level of administrative complexity and environmental uncertainty facing the firm. Overall, our theory and results enhance our understanding of 'why top management teams are composed the way they are', by highlighting the impact of internal and external hiring modes in the selection of demographically (dis)similar executives.
\end{abstract}

Keywords: executive appointments, diversity, top management teams, upper echelons 


\section{Introduction}

Strategic leadership research has long acknowledged the importance of understanding the antecedents and consequences of top management team (TMT) composition (Chaganti \& Sambharya, 1987; Guthrie \& Datta, 1997; Carpenter, Geletkanycz \& Sanders, 2004; Hambrick, 2007; Greve, Biemann, \& Ruigrok, 2015; Oehmichen, Heyden, Georgakakis \& Volberda, 2017). Despite substantial progress in this area, the selection of individual executives to the most dominant decision-making body of the firm (i.e., the TMT) is a topic that remains relatively unexplored (Finkelstein, Hambrick \& Cannella, 2009). Understanding the hiring modes (i.e., internal promotion versus external hiring) through which firms appoint dissimilar top managers is important, as it will eventually allow us not only to enhance our understanding of "why do top management teams look the way they do" (Hambrick, 2007: 338), but also to appreciate the role of executive selection practices in affecting the attributes of newly appointed TMT members.

In this study, we address this important topic by examining the relationship between the hiring origin and the demographic dissimilarity of incoming executives. Extant studies have described the countervailing forces that determine TMT composition (Boeker \& Wiltbank, 2005; Boone, van Olffen, van Witteloostuijn, \& de Brabander, 2004). On the one hand, theories of homosocial reproduction suggest that micro-level psychological factors - such as similarity attraction - lead to a preference for individuals who demographically resemble incumbent team members (Boone et al., 2004; Kanter, 1977; Schaubroeck, Ganster, \& Jones, 1998). On the other hand, studies adopting a resource-based perspective suggest that meso- (organizational) and macro(environmental) level forces encourage firms to increase TMT diversity by selecting executives who are dissimilar to the existing group (Boeker \& Wiltbank, 2005; Boone et al., 2004; Carpenter, 2002; Nielsen, 2009; Pennings \& Wezel, 2010). 
Drawing on the Person-Group (P-G) fit literature (Seong, Kristof-Brown, Park, Hong \& Shin, 2015; Werbel \& Johnson, 2001) we add to this discussion by suggesting that different hiring modes (i.e. internal versus external hiring) affect how firms respond to similarity attraction inclinations. According to the P-G fit perspective, supplementary fit refers to the similarity in values among individuals and groups (Seong et al., 2015). Prior studies have suggested that sociodemographic characteristics reflect the underlying values, beliefs and perceptual filters of individuals (Williams \& O'Reilly, 1998; Nielsen \& Nielsen, 2013). If there is no prior information gained through an individual's tenure in the team or the organization, the P-G fit of a sociodemographically dissimilar candidate will be perceived as lower (Werbel \& Johnson, 2001). On this basis, we argue that as firms have information about the supplementary-fit of an internal candidate to the rest of the group through the former's prior tenure inside the organization, they are likely to pay less attention to the candidate's externally-observable demographic traits in evaluating his or her fit with the rest of the group - and thus exhibit a weaker tendency toward homogeneity reproduction in demographic attributes. On the other hand, when appointing an outsider, decision making teams will often lack detailed information to judge the supplementary-fit of the candidate to the group and the organization - owing to the external candidate's lack of firm-specific experience and prior socialization inside the organization. When evaluating an external candidate's potential to integrate in the group, decision makers will therefore rely more on externallyobservable demographic similarity between the candidate and the existing team. We argue that this will strengthen similarity attraction tendencies, and will result in a preference for hiring external candidates who socio-demographically resemble incumbent members.

Our study offers several contributions. First, it builds a bridge between the P-G fit literature (Kristof, 1996; Seong et al., 2015) and research on similarity attraction and social identity (Kanter, 1977; Schneider, 1987) to explain how and why firms select executives who demographically differ 
from incumbent TMT members. It shows that the core assumptions of social identity and similarity attraction theories about homogeneity reproduction in teams and working groups have stronger explanatory power for external hiring rather than for internal promotion decisions. In this regard, our work contributes to our understanding of how different modes of hiring executives can systematically result in the appointment of candidates with different characteristics.

Second, our study highlights the multilevel factors that affect executive selection decisions (Klimoski \& Koles, 2001). Past research has associated organizational complexity and environmental uncertainty with information-processing demands that drive firms to hire executives who are dissimilar to the rest of the group (Boeker \& Wiltbank, 2005; Boone et al., 2004). Our work contributes to a more nuanced view on the effects of these contingency factors. It demonstrates that administrative complexity reduces the negative relationship between external hiring and demographic dissimilarity of new TMT members, while environmental uncertainty strengthens this relationship. In this regard, our theory and results challenge traditional wisdom on how these contingency factors impact TMT configuration. Overall, our work stresses that the demographic profiles of newly appointed TMT members are subject to the boundary conditions surrounding the organization at the time of executive selection.

\section{Theory and Hypotheses}

The selection of executives is typically a joint effort of the CEO and other governance bodies, including the incumbent TMT (Cannella \& Holcomb, 2005; Finkelstein et al., 2009). Given the distinct role of top managers in making decisions that are highly critical for organizations, scholars have acknowledged that actual executive selection practices vary widely from one case to the next - ranging from relatively loose informal approaches to rigid formalized processes (Carpenter et al., 2004; Klimoski \& Koles, 2001). Scholars have also noted that executive selection practices differ 
widely compared to selection of team members at lower levels of the organizational hierarchy (Hollenbeck, 2009). Executive selection, succession, and replacement are often affected by internal dynamics and external contingencies that affect the interaction of TMT members and the functioning of TMTs (Georgakakis \& Ruigrok, 2017; Shen \& Cannella, 2002). These particularities and idiosyncrasies of executive selection are important to bear in mind as we outline the drivers toward homosocial reproduction and heterogeneity in TMTs.

\section{Drivers Toward Homosocial Reproduction}

Social identity and similarity attraction theories provide the conceptual foundations of homogeneity reproduction in working groups (McPherson, Smith-Lovin \& Cook, 2001; Kanter, 1977; Tajfel, 1974; William \& O’Reilly, 1998). This stream suggests that individuals are inherently inclined to like, trust and interact with similar others, while at the same time dislike, mistrust and avoid interaction with outgroup members (Schneider, 1987). Due to their inherent similarity attraction inclinations at the time of executive selection, management groups are likely to reproduce their characteristics by selecting new TMT members who demographically resemble the incumbent team (Kanter, 1977). There are two main mechanisms which drive this phenomenon.

First, due to similarity attraction inclinations, demographic resemblance increases the likelihood of positive evaluations at the time of executive selection (Kanter, 1977). According to Latham, Wexley and Pursell, "the more closely an assessee resembles the rater in attitudes and background, the stronger the tendency of the rater to judge that individual higher" (1975: 551). The inherent inclination to evaluate similar others more favorably (Kanter, 1977) prompts dominant groups to appoint new team members who are demographically similar to themselves, and reproduce homogeneity over time (Schneider, 1987).

Second, candidates who are demographically dissimilar to incumbents generate more uncertainty at the time of selection with regard to their post-appointment supplementary-fit 
(Edwards, 2008) and integration in the existing team (Jackson, Stone, \& Alvarez, 1993; Kanter, 1977). Due to social identity inclinations that affect interpersonal interaction in the post appointment stage, decision-makers may perceive a demographically dissimilar candidate as more difficult to integrate in the group. This uncertainty concerning the post-appointment integration of dissimilar candidates encourages incumbents to select new team members who resemble themselves in socio-demographic characteristics. Indeed, Kanter (1977) pointed out that "one way to ensure acceptance and ease of communication was to limit managerial jobs to those who were socially homogeneous" (1977: 58).

\section{Drivers of Hiring Socio-demographically Dissimilar Executives}

Whereas social identity and similarity attraction arguments predict the homogenization of dominant groups (Williams \& O’Reilly, 1998), resource-based perspectives underscore the mesoand macro-level forces that encourage the selection of dissimilar others (Keck \& Tushman, 1993). To effectively navigate competitive environments and engage with diverse stakeholders, firms must have the ability to solve complex problems and respond to heterogeneous external demands by seeking advice from inside or outside the organization (Heyden, van Doorn, Reimer, van den Bosch \& Volberda, 2013). Indeed, existing research suggests that meso- and macro-level factors stimulate the pursuit of TMT diversity (Keck \& Tushman, 1993), and may also moderate the propensity to select dissimilar executives under certain conditions (Boone et al., 2004; Nielsen, 2009).

From a resource-based perspective, diversity in demographic characteristics provides a team with a range of individual backgrounds and mindsets that are necessary to respond to the variety of internal and external stakeholder demands surrounding the organization (Jackson, Joshi \& Erhardt, 2003; Phillips, Liljenquist \& Neale, 2009; Richard, 2000). Top managers with diverse 
demographic attributes are likely to act as effective vehicles of decision making and problemsolving (Cohen \& Bailey, 1997; Milliken \& Martins, 1996). Hiring executive candidates who are dissimilar to incumbent top managers can thus serve as a strategic response to contextual demands (Nielsen, 2009).

At the macro-level, executive leaders serve an important role in linking the firm with its environment (Hambrick, Finkelstein \& Mooney, 2005) by acting as boundary spanners who provide a variety of resources to the firm (Carpenter \& Fredrickson, 2001). Indeed, past research has underscored the need for executive leaders with diverse characteristics and cognitive schemas at firms that operate in challenging environments (Finkelstein et al., 2009). The heterogeneous demands facing TMTs (Hambrick et al., 2005) will thus prompt the appointment of dissimilar executives, thereby enhancing the overall cognitive capacity of the TMT as well as its ability to assess a wider variety of options in strategic decision making.

\section{The Role of Hiring Modes: A Person-Group Fit Perspective}

The P-G fit perspective has emerged as a subcategory within the broader Person-Environment (PE) fit literature (Edwards, 2008; Werbel \& Johnson, 2001). It implies that - when making selection decisions - recruiters attempt to evaluate a candidate's complementary- and supplementary-fit with the rest of the existing group. While the complementary-fit most often refers to the complementarities of a candidate in terms of job-related attributes, the supplementary-fit refers to the compatibility (or similarity-fit) between a person and the incumbent group (Kristof-Brown \& Guay, 2011). In this regard, scholars have argued that if firms manage to enhance the supplementary-fit between new hires and the rest of the team, they are likely to realize higher job satisfaction and team cohesion, thus producing desirable group-level outcomes (Werbel \& Johnson, 2001). 
To judge the supplementary-fit of a candidate with the rest of the group, decision makers can consider two types of characteristics: (a) 'externally observable characteristics', including socio-demographic traits such as age, gender, and nationality, and (b) 'unobservable attributes' such as information about candidates' socialization and integration in prior positions (Bills, 1999; Werbel \& Johnson, 2001). While the latter type provides objective information about an individual's ability to integrate and fit with the processes, purpose, and functioning of the group, the former provides information about the socio-demographic attributes of the individual (Bills, 1999). For internal candidates, firms are likely to judge the person's supplementary-fit by focusing on the privileged information they have about the candidate's past tenure and socialization inside the organization, rather than by paying attention to the individual's socio-demographic characteristics (Edwards, 2008). This is because information gained through a candidate's prior tenure inside the firm is a relatively more accurate predictor of the candidate's potential supplementary-fit and propensity to integrate with the rest of the group and the organization (Kristof-Brown, Zimmerman \& Johnson, 2005). Hence, the externally observable sociodemographic characteristics of internal candidates will be perceived as being of limited importance in the selection process.

On the other hand, for external candidates, socio-demographic resemblance with the incumbent TMT is likely to play a stronger role at the time of selection. As firms and decisionmaking teams often lack information about an outsider's socialization and assimilation potential, they are more likely to pay attention to observable attributes in judging his or her supplementaryfit to the incumbent group. For external candidates, observable socio-demographic similarity may be (consciously or unconsciously) perceived as a substitute for the relative lack of privileged information about the candidates' integration potential (Jackson, et al., 1993; Zajac \& Westphal, 1996). Since observable socio-demographic similarity is seen as an inherent proxy of the 
supplementary-fit when other objective information is unavailable (Werbel \& Johnson, 2001; Cable \& Edwards, 2004), we expect that external hiring of executives will be associated with a preference for socio-demographically similar candidates. It is important to note that we focus on the socio-demographic attributes of executives - and not on their experience-related characteristics - as the former are more likely to be associated with social-identity tendencies in executive selection, while the latter are more likely to be determined by job- and position-related requirements (see the Methodology section for a more detailed discussion). On this basis, we predict a negative relationship between external hiring and socio-demographic dissimilarity of new appointees to the incumbent group - as follows:

Hypothesis 1: External hiring is negatively related to the demographic dissimilarity between a newly appointed executive and the rest of the TMT.

\section{Organizational and Environmental Contingencies}

Prior research has emphasized the role of internal and external contingencies in affecting executive selection decisions (Greve et al., 2015; Naveen, 2006). Studies, for example, have argued that both firm-level complexity and environmental uncertainty impose higher informational demands on the TMT (Hambrick et al., 2005), and thereby drive executive teams to appoint new TMT members who socio-demographically differ from the existing group (Nielsen, 2009). In this study, however, we argue that administrative complexity (proxied as the number of employees) and environmental uncertainty (proxied as industry dynamism) will have opposing moderating effects on the relationship between external hiring and dissimilarity of new appointees.

Administrative complexity is primarily defined by past decisions made by the firm's management, and is therefore widely perceived to be within the TMT's scope of control. Top managers can increase or decrease the firm's level of administrative complexity as they can make 
decisions that directly impact on the size and scope of the organization (Hambrick, 2007). Environmental uncertainty, meanwhile, mainly depends on external circumstances, and is thus perceived to be a factor that is largely beyond management's control (Dess \& Beard, 1984; Thompson, 1967). The level of environmental uncertainty is mainly determined by macro-level exogenous factors, such as those emanating from economic and technological changes (Bergh \& Lawless, 1998; Hill \& Hoskisson, 1987). Thus, top managers' ability to influence such factors is mostly limited. We emphasize this distinction because we contend that the difference in perceived controllability has a crucial impact on the decision-makers' psychological response to external contingency factors in TMT appointment decisions (Das \& Teng, 1999). We therefore expect that administrative complexity and environmental uncertainty will have different moderating effects on the relationship between external hiring and dissimilarity of new executives. Below, we expand on this logic and develop the corresponding hypotheses.

\section{Administrative Complexity}

As larger firms face more complex administrative demands in dealing with a diverse set of employees and internal stakeholders, large workforce size has often been conceptualized as a proxy

of firm-level administrative complexity (Miller, 1987). There are two main reasons why we expect the negative relationship between external hiring and dissimilarity of new executives to become less pronounced under such conditions. First, as large and complex firms possess a wider pool of internal candidates, the perception of controllability is likely to be relatively high - even if the appointment of a dissimilar outsider to the TMT proves to be a wrong decision - due to the availability of fallback options in the large internal labor market. The perceived controllability will drive large complex organizations to be more open in hiring dissimilar executives from outside the firm, thus enhancing the information-processing and boundary-spanning capacity of the TMT. 
Second, large workforce size implies that top managers will have to deal with greater decision making complexity (Bushman, Chen, Engel, \& Smith, 2004; Damanpour, 1996; Denis, Denis, \& Yost, 2002). To effectively respond to high information processing demands and enhance perceived controllability, TMTs at large firms are likely to view the appointment of sociodemographically dissimilar executives from outside the firm as a way to increase their ability to manage, control, and respond to the informational demands facing the executive group. Put differently, the appointment of individuals who can contribute to the overall resource configuration of the executive group through: (a) their external knowledge, and (b) their socio-demographic differences to the rest of the group (Cohen \& Bailey, 1997; Haleblian \& Finkelstein, 1993) will be perceived as a vehicle to control and respond to the greater variety of demands that derive from a large workforce size.

Hypothesis 2: The negative relationship between external hiring and demographic dissimilarity of newly selected executives is less pronounced under conditions of high administrative complexity.

\section{Environmental Uncertainty}

Environmental uncertainty refers to the extent to which an organization's external (industry) environment is characterized by volatility and unpredictability (Dess \& Beard, 1984). Similar to conditions of organizational complexity, access to diverse resources and problem-solving capacities at TMT level can help firms to deal with environmental uncertainty (Cannella, Park \& Lee, 2008; Nielsen, 2009). However, environmental uncertainty has the added distinctive feature of being exogenously determined, and thus, not directly controllable by the firm's management (Dess \& Beard, 1984). Studies have shown that under conditions of low managerial controllability, 
and high environmental uncertainty, firms are inclined to reduce the unpredictability that characterizes micro-level selection decisions (Johnson, 1988). From a psychological perspective, TMTs are likely to perceive greater uncertainty when they appoint a dissimilar executive from outside the firm, rather than from within the organization. As environmental uncertainty generates a need to reduce unpredictability in making decisions (Johnson, 1988), we expect that it will strengthen the predicted tendency of firms to appoint candidates who are dissimilar to incumbents from inside, rather than from outside the organization.

Indeed, this argument is in line with the behavioral decision literature, which suggests that firms adopt conservative approaches to decision making under uncertain environmental conditions (Das \& Teng, 1999; Weick, 1979). In response to environmental uncertainty, management teams strive to mitigate unpredictability in micro-level decisions. They do so to ensure "that even if some unexpected outcomes [of a decision] were to materialize, they would be able to manage or control the situation" (Das \& Teng, 1999: 768). As the decision to select a dissimilar candidate for a top management position implies higher micro-level unpredictability (Petersen \& Saporta, 2004), environmental uncertainty is expected to rather strengthen the negative relationship between external hiring and dissimilarity of newly appointed TMT members. Thus, we derive the following hypothesis:

Hypothesis 3: The negative relationship between external hiring and demographic dissimilarity of newly selected executives is more pronounced under conditions of high environmental uncertainty. 


\section{Data and Methods}

\section{Sample and Data Collection}

The initial sample consisted of all 1243 non-CEO executive appointments that occurred at 310 listed firms headquartered in four West-European countries (i.e. Germany, the Netherlands, Switzerland, and the United Kingdom) over the period 2005 to 2009. All publicly listed firms in each of the four countries were ranked by market capitalization at the end of 2005 (December $31^{\text {st }}$ ), and the largest 100 firms per country were included provided that they met the following conditions: (1) they were not compatible with the European Union's definition of a small and medium-sized enterprise at year-end 2005 (i.e. they had at least 250 employees and not less than $€ 50$ million annual revenues); and (2) they were not acquired by other firms or ceased to operate between 2005 and 2009. We focus on the period 2005 to 2009 as it provides a balanced number of years before and after the financial crisis - allowing us to control for potential crisis-related effects, and thereby enhance the generalizability of our results.

From the initial sample of 1243 individual executive appointments, 668 observations had to be dropped due to data unavailability, resulting in a final sample of 575 non-CEO executive appointments at 170 firms. Focusing on the dissimilarity of individual executives enables us to examine how firms make individual-level appointment decisions - an aspect which is in line with the P-G fit logic. In addition, having the individual-level as our lowest level of analysis, allows us to observe variance decomposition effects of individual-, team/firm-, and industry-level factors in explaining the demographic dissimilarity of individual appointees (e.g., Nielsen, 2009). The firms included in our final sample were nested within 38 industries based on their primary two-digit standard industry classification code. As a test for differences between our sample observations and the initial population, we ran t-tests comparing the mean of our dependent variable (sociodemographic dissimilarity) and our predictor variable (external hiring) between missing and non- 
missing observations. These tests showed no significant differences in the means of the two subsamples.

The four Western European countries were chosen for two reasons. First, the four countries are preferred homes for many large corporations which attract a pool of executive candidates with diverse demographic profiles - offering a suitable context to assess the selection of sociodemographically dissimilar executives. Second, these four countries have long established corporate reporting practices that allowed us to obtain detailed information from the public domain at the time of data collection. Individual executives' demographic and background data was manually collected from firms' annual reports and corporate websites. Firm- and industry-level data was gathered from the ThomsonONE database. Consistent with prior TMT studies with European samples, we defined the TMT as the highest level of corporate management by relying on firms' self-reported definitions provided in annual reports (Greve et al., 2015; Nielsen \& Nielsen, 2013).

We follow previous studies that have separately examined non-CEO executives (Athanassiou \& Nigh, 2002; Carpenter \& Wade, 2002). As the appointment of a CEO is a substantively different decision than the appointment of other TMT members (Finkelstein et al., 2009; Shen \& Cannella, 2002), we exclude CEO appointments from our main analysis. Indeed, scholars have argued that, due to the CEO's role as the leader of the TMT (Georgakakis, Greve \& Ruigrok, 2017; Heyden, Reimer \& van Doorn, 2017), CEO replacement and succession is influenced by multiple factors which are distinct from the selection of non-CEO executives (Cannella \& Georgakakis, 2017; Harvey, Currall \& Hammer, 2017, Finkelstein et al., 2009; Klimoski \& Koles, 2001). Such factors have to do with the greater level of managerial discretion CEOs have in terms of making strategic decisions (Cannella \& Holcomb, 2005), as well as selecting other senior executives (Klimoski \& Koles, 2001). The appointment of a new CEO is 
thus more likely to be determined either by the predecessor CEO (Krause, 2017) or by the board of directors (Westphal \& Zajac, 1995). Thus, focusing on non-CEO appointments enhances the internal consistency of our dependent variable.

Further, scholars have argued that CEOs are likely to exert a significant influence on who is hired, and who is fired, in the TMT (Cannella \& Holcomb, 2005). To check the CEO's distinct influence in executive selection decisions, we re-ran our analysis using new appointees ${ }^{\text {}}$ dissimilarity with the CEO as an alternative dependent variable. This analysis provides similar results to those presented in Table 3 - with most of our hypotheses supported, albeit with a weaker overall model. This suggests that even in situations where CEOs have high degrees of managerial discretion, they will select candidates by considering their supplementary-fit to the rest of the team - rather than their individual-level demographic similarity with the candidate. This is in line with upper echelons theory, which suggests that it is not the CEO alone, but rather the entire TMT that influences executive selection decisions (Hambrick \& Mason, 1984; Klimoski \& Koles, 2001). In addition, the P-G perspective suggests that candidates are screened based on their supplementaryfit with the entire group, not just with the leader of the team (Seong et al., 2015; Werbel \& Johnson, 2001). Following this theoretical logic, we present our results based on the dissimilarity of new hires to the rest of the TMT (i.e., including the CEO).

\section{Dependent Variable}

Our dependent variable is the overall degree of dissimilarity of each newly selected non-CEO executive relative to incumbent TMT members. The overall dissimilarity measure is a composite of dissimilarity in three attributes: age, gender, and nationality. These attributes have been widely employed in past studies as socio-demographic characteristics of executives (e.g., Heyden, Sidhu \& Volberda, 2015), and have often been distinguished from other job-related attributes (e.g., 
functional background) (Georgakakis et al., 2017; Bezrukova, Jehn, Zanutto \& Thatcher, 2009; Hutzschenreuter \& Horstkotte, 2013). Importantly for this study, these three attributes are sociodemographic characteristics (Bell, Villado, Lukasik, Belau \& Briggs, 2011), and have often been regarded as triggers of social-identity and similarity attraction inclinations at the time of executive selection (Nielsen, 2009; Greve et al., 2015).

The composite dissimilarity measure consists of one continuous component (age) and two categorical components (gender and nationality). Age, gender, and nationality are widely employed in the literature as key dimensions of socio-demographic differences in TMTs (Dezsö \& Ross, 2012; Richard \& Shelor, 2002; Ghemawat \& Vantrappen, 2015; Ruigrok \& Greve, 2008; Van Veen \& Marsman, 2008). In this study we have not considered race, which is another important externally observable demographic attribute, for two reasons. First, there is no standard classification of race or ethnicity in Europe (Farkas, 2017) and European firms rarely report on the race or ethnicity of individual executives, thus making it difficult to collect accurate data. Second, nationality is arguably more closely associated with the underlying values and leadership behavior of individuals - and is thus more likely to influence executive selection decisions (Nielsen, 2009; Nielsen \& Nielsen, 2013).

Similar to prior studies with European samples, nationality was defined as the primary nationality of an executive team member (Greve et al., 2015; Nielsen \& Nielsen, 2013; Nielsen, 2009). Gender was a dichotomous variable taking the value of 1 if a TMT member was female and 0 otherwise. In line with prior studies (Tsui, Egan \& O’Reilly, 1992), we calculated dissimilarity in terms of age, gender, and nationality between a newly appointed executive and incumbent TMT members using the distance formula expressed as: $\sqrt{\frac{1}{n} \sum_{j=1}^{n}\left(S_{i}-S_{j}\right)^{2}}$. For age $S_{\mathrm{i}}$ represents the age (in years) of a newly appointed executive $\mathrm{i}$, and $\mathrm{S}_{\mathrm{j}}$ represents the age (in years) of each incumbent executive $\mathrm{j}$. For categorical variables, $\mathrm{S}_{\mathrm{i}}$ represents the attribute of an individual appointee, and $\mathrm{S}_{\mathrm{j}}$ 
the attribute of each TMT member. To obtain a composite measure of dissimilarity for each newly appointed executive, we normalized age dissimilarity to take values between 0 and 1 and aggregated age, nationality, and gender dissimilarity into an overall measure (see also: Boone et al., 2004; Schaubroeck \& Lam, 2002).

We employed a composite measure of dissimilarity in observable demographic attributes for the following reason. According to Boone et al., "the distance of a manager from other team members can best be assessed by cumulating distances along several dimensions" (2004: 640). At the time of hiring, firms evaluate an executive candidate based on an overall compatibility assessment, in which they consider multiple characteristics simultaneously rather than individual attributes separately (Pelled, Eisenhardt \& Xin, 1999). Thus, a composite measure is most suitable for examining the antecedents of a new appointee's demographic dissimilarity to the rest of the team.

Finally, we decided to focus on socio-demographic attributes rather than job-related characteristics (e.g., functional background, field of education) as they are less task related in nature, and thus, more influenced by similarity attraction inclinations in the context of executive selection. For instance, when the TMT seeks to appoint an individual to fill the Chief Financial Officer's position, the team will have to search for a person with functional expertise in finance regardless of whether this expertise is similar or different to the experiences of other executives. Given that our argumentation builds on social identity and similarity attraction theories, and as TMTs need to appoint executives with functional background based on the requirements of the executive position (rather than the candidates' social similarity to other group members), focusing only on socio-demographic attributes provides a stronger correspondence between our theorizing and measurement of interpersonal dissimilarity in executive groups. 


\section{Independent and Moderator Variables}

We measured the hiring mode as a dichotomous variable taking the value of 1 if a newly appointed executive was hired from outside the firm and 0 otherwise. In line with other studies, we define externally appointed executives as those who did not possess any prior intra-firm working experience at the time of their initial appointment to the TMT (Shen \& Cannella, 2002).

Administrative complexity was conceptualized as firm size (number of employees) (Tihanyi, Ellstrand, Daily, \& Dalton, 2000). Prior studies have shown that the larger the size of the workforce, the greater the level of complexity facing the executive group. This is owing to the greater variety and volume of tasks and decisions that are likely to be referred to the TMT in an organization with a larger number of employees (Bacon \& Hoque, 2005; Guest, Michie, Conway \& Sheehan, 2003; Thompson, 1967). Thus, we employ workforce size (number of employees) as a proxy of administrative complexity. Similar to prior studies, we logarithmically transformed the size variable to reflect diminishing effects at the upper end of the scale (Tihanyi et al., 2000).

Environmental uncertainty was captured using Dess and Beard's (1984) measure of environmental volatility. To calculate this variable, we computed the regression coefficient of time on the annual average sales in a firm's primary four-digit industry during the three years prior to each executive appointment. Subsequently, we divided the standard error obtained from the regression slope coefficient of each industry by the average sales (Zhang \& Rajagopalan, 2004).

\section{Control Variables}

The variable incumbent TMT diversity was used to control for the ex-ante heterogeneity of the incumbent TMT (including the CEO) prior to a new executive appointment. The initial level of TMT diversity is likely to vary widely across firms, and to influence the inclination toward appointing a dissimilar TMT member (Boone et al., 2004; Nielsen, 2009). To calculate age 
diversity, we used the coefficient of variation by dividing the standard deviation of a team's age in a given year by its mean (Backes-Gellner \& Veen, 2013; Richard \& Shelor, 2002). To calculate gender and nationality diversity, we used the widely applied Blau (1977) formula $1-\Sigma \mathrm{p}_{\mathrm{i}}{ }^{2}$, where $\mathrm{p}$ is the proportion of team members in the demographic category $i$. The Blau index is widely regarded as an appropriate metric to capture diversity as variety in teams (Harrison \& Klein, 2007). To develop a composite variable, we normalized age diversity and aggregated all components in a single measure (Boone et al., 2004).

We also controlled for the degree of functional background diversity in the TMT using the Blau (1977) index. The functional background of executives was measured as the dominant function, i.e. the function in which the executive has spent the largest proportion of his or her career (Bunderson \& Sutcliffe, 2002). In line with Cannella et al. (2008), we coded the dominant function of each individual executive in one out of seven functional tracks: $R \& D$ and engineering; accounting and finance; management and administration; marketing and sales; law; personnel and labor relations; other (see also: Oehmichen et al., 2017; Tuggle, Schnatterly \& Johnson, 2010).

Further, we employed the firm's degree of internationalization (DOI) as a control variable to account for the strategic complexity facing the organization. Including this variable allows us to test the effect of administrative complexity (number of employees) by taking into consideration the level of strategic complexity (proxied as DOI) of the firm. Similar to prior studies, the degree of internationalization is measured as the ratio of foreign sales to total sales in each respective appointment year (Collins, 1990; Tallman \& Li, 1996).

We also controlled for CEO firm tenure, by taking the number of years that the CEO has worked inside the firm. We used a logarithmic transformation of this variable to capture the diminishing effects of CEO firm tenure over time (Hambrick \& Fukutomi, 1991). Controlling for this variable is key, as long tenured CEOs are more inclined to select executives from inside the 
organization (Shen \& Cannella, 2002) and enjoy greater levels of discretion in making executive selection decisions (Finkelstein et al., 2009). Further, we controlled for the educational level of TMT members. Similar to prior studies (e.g., Heyden et al., 2015), advanced education was measured as a dichotomous variable taking the value of 1 if an individual executive holds a Master's degree (including MBA) or a doctorate, and 0 otherwise.

TMT size was included as a control variable to account for the notion that large TMTs may be inclined to replace team members more frequently (Greve et al., 2015). TMT size was coded as the number of TMT members in the year of appointment. This variable was logarithmically transformed to capture the diminishing effects of larger team size (Boeker, 1997; Tihanyi et al., 2000). Finally, we controlled for past firm performance. Research has shown that poorly performing firms are more likely to alter TMT composition (Greve et al., 2015; Pennings \& Wezel, 2010; Wiersema \& Bantel, 1992). Thus, we controlled for the three-year average return on assets prior to each executive appointment.

\section{Analytical Strategy}

As our data is based on three different levels of analysis (i.e. individual, firm, and industry), we employed a three-level hierarchical linear modeling (HLM) technique (Raudenbush \& Bryk, 2002). At the first level of analysis, the study investigates differences between individual appointees nested within firms/teams. At the second level, the study considers differences between firms/teams nested in industries, whereas differences between industries are observed at the third level of analysis. Centering decisions are important in multilevel models. In analysis that includes crosslevel interactions, centering to the grand mean is usually the preferred option (Bliese, 2000). Since our models and hypotheses include cross-level interactions, we centered variables to the grand mean (Raudenbush \& Bryk, 2002). 
To account for potential endogeneity and sample-selection issues, we employed a Heckman two stage approach (Karaevli \& Zajac, 2013; Quigley \& Hambrick, 2012; Weng \& Lin, 2014). The most crucial issue for the effective operationalization of Heckman's (1979) model is to identify suitable instrumental variables that are significantly correlated with the independent variable (i.e. external hiring) and not significantly correlated with the dependent variable (i.e. new appointees' dissimilarity in our case) (Semadeni, Withers \& Certo, 2014). In line with recent executive selection literature (Karaevli \& Zajac, 2013), we employed the rate of external hiring in the industry as an instrument in our study. Correlation results indicate that the chosen instrumental variable is suitable for our study, as it is highly correlated with external hiring $(r=0.23, p<0.001)$, and not significantly correlated with the dependent variable in the final sample of 575 executive appointments $(\mathrm{r}=-0.06, \mathrm{p}>0.10)$.

At the Heckman first stage, we conducted a Probit regression analysis to predict the likelihood of appointing a new executive from the external labor market. This included the full sample of firms that experienced TMT transition and firms that did not. Results of the Probit first stage analysis are presented in the Appendix. The inverse Mill's ratio predicted in the first stage model was then included as a control in the main analysis (see Table 3) - allowing us to account for potential endogeneity and sample selection issues.

\section{Results}

Table 1 displays descriptive statistics and correlations. Table 2 presents results of the null HLM model. Variance decomposition allowed us to consider the extent to which the variance in the dependent variable is explained by each level of analysis (Raudenbush \& Bryk, 2002). Results show that the individual-level and the firm-level explained the highest proportion of variance in the dependent variable with 47 percent and 42 percent respectively. This means that the 
dissimilarity of newly appointed executives is mainly explained by the attributes of the individual executive, as well as by firm-level factors. The third level represented a smaller proportion of variance with 11 percent, which means that the industry level does matter, albeit to a lesser extent. The results of the null model (see Table 2) are statistically significant at $\mathrm{p}<0.001$.

\section{INSERT TABLES 1 AND 2 ABOUT HERE}

Table 3 presents results of the main analysis. Model 1 displays results with control variables only, while Models 2 to 5 present results including the main predictor and interactions. In support of Hypothesis 1, Model 2 shows a negative relationship between external hiring and dissimilarity of newly appointed executives $(\mathrm{p}<0.01)$. Further, in support of Hypothesis 2 , Model 3 shows that the negative relationship between external hiring and new appointees' dissimilarity becomes less pronounced at firms facing high administrative complexity $(\mathrm{p}<0.05)$. As Figure 1 illustrates, high levels of administrative complexity weaken the negative relationship between external hiring and dissimilarity of new executives. It is worth noting, however, that this relationship receives only partial support in the full model (Model 5 in Table 3 ) with $p<0.10$. This suggests that we should be somewhat cautious in our interpretations of this finding. Further, in support of Hypothesis 3, Model 4 shows that the negative association between external hiring and dissimilarity of newly appointed executives is more pronounced under conditions of high environmental uncertainty $(\mathrm{p}<0.05)$. Figure 2 depicts this relationship, demonstrating its strengthening effect under conditions of high environmental uncertainty.

INSERT TABLE 3 ABOUT HERE 


\section{INSERT FIGURES 1 AND 2 ABOUT HERE}

\section{Supplementary Analysis ${ }^{1}$}

Recent studies highlight the need to examine demographic characteristics separately in order to understand the impact of TMT diversity on organizations (e.g. Carpenter et al., 2004; Nielsen \& Nielsen, 2013). To assess the impact of using a multi-dimensional dissimilarity construct as opposed to single-dimension constructs as dependent variables, we decomposed our multidimensional dissimilarity construct and ran separate HLM analyses for each of the three demographic dissimilarity components (i.e. employing gender dissimilarity, nationality dissimilarity, and age dissimilarity as dependent variables separately). Results show that external hiring has a negative and marginally significant effect $(\mathrm{p}<0.10)$ on age dissimilarity and a negative and significant effect on nationality dissimilarity $(\mathrm{p}<0.05)$. At the same time, external hiring did not exhibit a significant effect on gender dissimilarity $(\mathrm{p}>0.10)$. However, following the theoretical argument that firms simultaneously consider all demographic attributes to assess the fit of a candidate to the group (Boone et al., 2004) we only present results with the overall dissimilarity as dependent variable.

In addition, we tested the robustness of our results by adjusting our dependent variable to the year average. This enabled us to consider whether the observed effects are influenced by the financial crisis which occurred in the year 2007 - which is in the middle of the observed period.

\footnotetext{
${ }^{1}$ Results of the supplementary analyses are available upon request from the authors.
} 
Results of this supplementary analysis with the dependent variable adjusted at the year average are similar to those presented in this study - confirming the robustness of our results.

\section{Discussion}

Our study offers several contributions to extant strategic human resource management, upper echelons, and TMT diversity research. First, while some studies have found that TMTs are inclined to reproduce homogeneity over time by hiring executives who demographically resemble incumbents (Boone et al., 2004), research evidence shows that environmental and organizational factors encourage firms to select demographically dissimilar executives (Greve et al., 2015; Nielsen, 2009). Our study adds a new element to this discussion. It shows that dissimilar top managers are more likely to be promoted from inside the firm, while external hiring often results in homosocial reproduction. It also demonstrates that this relationship significantly varies with the multilevel contingencies surrounding the organization at the time of executive selection. From a theoretical viewpoint, our findings suggest that even when dominant groups overcome their tendency toward reproducing homogeneity, they do so by appointing executives who have already worked with the organization - and have thus been assimilated to the processes, culture, and internal aspects of the firm. To this end, our study constitutes a step toward answering the question of "why do TMTs look the way they do" (Hambrick, 2007: 338), by highlighting the importance of the hiring origin of newly appointed executives.

The observed negative relationship between external hiring and dissimilarity of new executives has important implications for the P-G fit literature. Prior research in this area poses interpersonal similarity as a vehicle for ensuring a supplementary fit between a new appointee and other group members. Our results, however, suggest that this assumption is more likely to hold true for external hires. It may be that firms often possess less information about the external candidates' 
supplementary-fit with the organization and the existing top management group, and thereby place more emphasis on their externally observable demographic traits when making selection decisions. At the same time, for internal candidates, demographic similarity is likely to play a less important role at the time of the executive selection process. Firms can assess the internal candidate's supplementary-fit to the group by considering directly his or her prior record and socialization inside the organization - rather than his or her similarity with incumbent group members in externally-observable socio-demographic attributes. In this regard, our study underscores the importance of hiring modes as key boundary conditions on how firms attempt to realize a supplementary-fit between newly selected individuals and the incumbent group.

Further, our results show that a firm's internal and external environment plays an important role in determining the attributes of newly appointed team members. Past studies have adopted a rational choice approach to argue that both organizational complexity and environmental uncertainty impose greater information processing demands on the TMT, and thus, they drive firms to select executive leaders with diverse backgrounds and characteristics (e.g. Nielsen, 2009). Our findings challenge this view by showing that these two contextual conditions have opposing effects on the relationship between external hiring and dissimilarity of new members. While organizational complexity increases the likelihood that firms appoint dissimilar top managers from the external labor market, environmental uncertainty is rather likely to strengthen the tendency of hiring dissimilar executives from inside the firm.

Indeed, the opposite moderating effects of administrative complexity and environmental uncertainty can be attributed to the subtle differences between these two constructs. High administrative complexity deriving from a large internal workforce is likely to provide top managers with the necessary confidence and experience to respond effectively to high informationprocessing demands. Such firms will therefore add the required variety of perspectives at the top 
of the firm, without the internal or external origin of candidates being a major consideration in the hiring process. In the case of an unsuccessful external appointment, decision makers in such firms will also have the fallback option of reverting to a large pool of internal candidates for a relatively quick replacement. Environmental uncertainty, on the other hand, is likely to elicit a different psychological response emphasizing incremental changes to preceding structures and paradigms (Das \& Teng, 1999; Weick, 1979). As an external factor that is beyond managerial controllability, high environmental uncertainty reinforces the need to attain a supplementary fit between external candidates and incumbent team members through incremental steps rather than radical changes i.e., either through the selection of outsiders who resemble incumbent members, or through internally promoted dissimilar executives.

Viewed in tandem, our findings show that similarity attraction inclinations in TMTs may ceteris paribus be fundamentally difficult to overcome. Our findings suggest that diversity in TMTs may primarily be developed by appointing dissimilar internal candidates who have already been socialized, assimilated, and groomed inside the organization. Externally appointed executives, on the other hand, are more likely to resemble the incumbent executives in externally observable social attributes. Individuals who have common firm specific backgrounds and shared intra-firm socialization are more likely to assimilate into the dominant groups and develop similar mental models and ways of thinking (Schneider, 1987). This may potentially supersede their underlying individual-level demographic differences, and thereby suppress the advantageous aspects that diversity and dissimilarity can offer to the group at the time of decision making (Shore, Randel, Chung, Dean, Ehrhart \& Singh, 2011). On the other hand, however, 'internally sourced diversity' may enable firms to make efficient use of variety in executive characteristics and backgrounds, as shared organizational experiences create a common platform upon which diverse viewpoints, knowledge, and resources can be leveraged (Georgakakis \& Ruigrok, 2017; Grossman, 2007). 
Broadly speaking, the outcomes of this study are important to enhance our understanding of diversity effects in strategic leadership. Viewed through the lens of a multilevel upper echelons framework (Cannella \& Holcomb, 2005), our work suggests that the appointment of dissimilar executives is an intermediate phenomenon that is simultaneously guided by micro-level executive hiring preferences and is influenced by meso- and macro-level boundary conditions. The negative relationship between external hiring and demographic dissimilarity of new executives suggests that TMT diversity evolves at the intersection between behavioral and rational logics that interdependently affect executive selection mechanisms. Future research can expand our model, and examine whether externally appointed executives are more likely to contribute to the overall knowledge-base and performance of the team when they socio-demographically resemble the existing group. This should be done by considering the multilevel factors surrounding the organization at the time of executive selection.

Further, our findings contribute to research on homosocial reproduction. They show that, in their effort to evaluate a supplementary-fit between the individual candidate and the rest of the group, firms are more likely to hire outsiders who socio-demographically resemble the rest of the executive team. This implies that the arguments of similarity attraction that lead groups toward homosocial reproduction (Schneider, 1987) have greater explanatory power when the firm appoints candidates from the external labor market, rather than internally. Future studies can expand our research model to investigate whether the appointment of outsiders who resemble the rest of the executive team reduces the likelihood of early departure or dismissal after their appointment (Zhang, 2008; Zhang \& Qu, 2016). In addition, studies can examine whether the appointment of dissimilar outsiders are likely to impact group-level dynamics, such as behavioral disintegration (Li \& Hambrick, 2005), or decision diversion in executive groups (Cannella \& Georgakakis, 2017; 
Harvey et al., 2017). This will help to understand the role of hiring modes in determining the selection and retention of externally hired executives.

\section{Implications for Practice, Limitations and Future Research}

Apart from its theoretical relevance, our paper has important practical implications. Research has argued that, since externally appointed executives are hired to act as problem-solving and information processing agents, they are expected to be dissimilar to incumbent executives in other demographic characteristics and backgrounds (Hambrick \& Fukutomi, 1991). This is because dissimilar-outsiders are likely to add different perspectives at the time of strategic decision making, enhancing the overall problem-solving and information processing capacity of the team (Jackson et al., 2003). However, our study challenges this point of view by showing that when firms appoint executives from outside the organizations, they tend to select candidates who are demographically similar to the incumbent team. Future research should test whether TMT diversity generated through external hiring is likely to overstretch the adaptive capacity of the candidate or the integrative capacity of the incumbent top management group (Grossman, 2007; Jackson, et al., 1993). A related avenue for future research would be to test whether external knowledge can more easily be transferred, and absorbed, when externally hired executives share common characteristics and backgrounds with incumbent TMT members (see e.g., Georgakakis \& Ruigrok, 2017; Grossman, 2007).

Our study is subject to some limitations that offer promising research avenues. First, we lack detailed data on the exact executive candidate pools to assess the relative success of dissimilar candidates in internal and external hiring processes. While our findings suggest that individuals with minority demographic characteristics are more likely to follow an internal path to the top, future survey-based or qualitative research is needed to advance our understanding of the career 
trajectories that are most beneficial for demographic minorities in overcoming imperfections in internal and external managerial labor markets. Second, the paper does not address the subsequent performance implications of hiring dissimilar executives from within and from outside the firm. A valuable extension of this study would be to examine whether dissimilar executives hired through internal promotion (as opposed to external appointments) are more - or less - likely to contribute positively to subsequent team and firm performance. Further exploration of the effects of internally versus externally sourced dissimilarity would help to improve our understanding of how individual executives are likely to contribute to the performance of the TMT and the organization.

Third, our study does not consider the power differentials that exist among team members. As suggested by Roberto (2003), the inner circle (i.e., stable core) of the most powerful strategic leader (i.e., the $\mathrm{CEO}$ ) may have a more influential role in affecting strategic decisions compared to the dynamic periphery (i.e., the less powerful TMT members). Indeed, some top managers may play a more important role than others in determining who is hired, and who is fired, in the TMT (Cannella \& Holcomb, 2005). In our study, we define the TMT based on the self-reported definitions provided in the firm's annual reports and corporate websites. While this archival data approach enables us to draw on a large sample and observe generalizable patterns, it comes with data limitations in terms of measuring interactions and power differentials among team members. Future research could use qualitative approaches, such as multiple case studies, to examine the impact of intra-TMT power differentials, and power struggles, in executive selection decisions.

Fourth, our study focuses only on three socio-demographic attributes to investigate the effects of similarity attraction and homogeneity reproduction in teams and working groups (i.e., age, gender and nationality). We focus on these attributes rather than job-related characteristics (e.g., functional background or field of education) as non task-related attributes are more likely to be influenced by similarity attraction inclinations in the context of executive teams. However, 
future studies can examine how external versus internal hiring modes affect the selection of dissimilar executives in terms of career background and experience - such as functional experience, international experience, field of education, or experience in turnaround situations. This would be in line with studies suggesting that there is no absolute distinction between relational and taskrelated diversity attributes (Ou, Seo, Choi \& Hom, 2016; Van Knippenberg, de Dreu \& Homan, 2004) and thus help to further elaborate our understanding of executive selection mechanisms in organizations' upper echelons. In addition, while our study considers nationality rather than race dissimilarity as (a) data on race is difficult to obtain in the context of European TMTs and (b) nationality is more closely related to the cultural values of individuals, future studies can examine the impact of race dissimilarity in executive selection decisions. Finally, our sample consists of large stock-listed firms in four Western European economies. Thus, our results are not necessarily generalizable to smaller non-listed firms, or to firms headquartered in other countries. Future research could thus assess the generalizability of our findings in different cultural and institutional contexts. 


\section{References}

Athanassiou, N., \& Nigh, D. (2002). The impact of the top management team's international business experience on the firm's internationalization: Social networks at work. Management International Review, 42, 157-181.

Bacon, N., \& Hoque, K. (2005). HRM in the SME sector: valuable employees and coercive networks. International Journal of Human Resource Management, 16, 1976-1999.

Backes-Gellner, U., \& Veen, S. (2013). Positive effects of aging and age diversity in innovative companies - large-scale empirical evidence on company productivity. Human Resource Management Journal, 23, 279-295.

Bell, S. T., Villado, A. J., Lukasik, M. A., Belau, L., \& Briggs, A. L. (2011). Getting specific about demographic diversity variable and team performance relationships: A meta-analysis. Journal of Management, 37, 709-743.

Bergh, D. D., \& Lawless, M. W. (1998). Portfolio restructuring and limits to hierarchical governance: The effects of environmental uncertainty and diversification strategy. Organization Science, 9, 87-102.

Bezrukova, K., Jehn, K. A., Zanutto, E. L., \& Thatcher, S. M. B. (2009). Do workgroup faultlines help or hurt? A moderated model of faultlines, team identification, and group performance. Organization Science, 20, 35-50.

Bills, D. B. (1999). Employers` use of history data in making hiring decisions: The tenuous balance between rewards, commitments, and costs. Sociological Forum, 14, 583-607.

Blau, P. (1977). Inequality and heterogeneity: A primitive theory of social structure. New York, NY: Free Press.

Bliese, P. D. (2000). Within-group agreement, non-independence, and reliability: Implications for data aggregation and analysis. In K. J. Klein \& S. W. Kozlowski (Eds.), Multilevel theory, research, and methods in organizations (pp. 349-381). San Francisco, CA: Jossey-Bass.

Boeker, W. (1997). Strategic change: The influence of managerial characteristics on organizational growth. Academy of Management Journal, 40, 152-170.

Boeker, W., \& Wiltbank, R. (2005). New venture evolution and managerial capabilities. Organization Science, 16, 123-133.

Boone, C., van Olffen, W., van Witteloostuijn, A., \& de Brabander, B. (2004). The genesis of top management team diversity: Selective turnover among top management teams in Dutch newspaper publishing. Academy of Management Journal, 47, 633- 656.

Bunderson, J. S., \& Sutcliffe, K. M. (2002). Comparing alternative conceptualizations of functional diversity in management teams: Process and performance effects. Academy of Management Journal, 45, 875-893. 
Bushman, R., Chen, Q., Engel, E., \& Smith, A. (2004). Financial accounting information, organizational complexity and corporate governance systems. Journal of Accounting and Economics, 37, 167-201.

Cable, D. \& Edwards, J.R., (2004). Complementary and supplementary fit: A theoretical and empirical integration. Journal of Applied Psychology, 89: 822-834.

Cannella, A. A. Jr., \& Georgakakis, D. (2017). Decision Diversion: The roles of leadership context and other contingencies. Academy of Management Discoveries, 3, 428-430.

Cannella, A. A. Jr., \& Holcomb, T. R. (2005). A multi-level analysis of the upper-echelons model. In F. Dansereau \& F. Yammarino (Eds.), Multilevel issues in strategy and methods (Vol. 4, pp. 195-237). Oxford: Elsevier.

Cannella, A. A. Jr., Park, J., \& Lee, H. (2008). Top management team functional background diversity and firm performance: Examining the roles of team member colocation and environmental uncertainty. Academy of Management Journal, 51, 768-784.

Carpenter, M. A. (2002). The implications for strategy and social context for the relationship between top management team heterogeneity and firm performance. Strategic Management Journal, 23, 275-284.

Carpenter, M. A., \& Fredrickson, J. W. (2001). Top management teams, global strategic posture and the moderating role of uncertainty. Academy of Management Journal, 44, 533-545

Carpenter, M. A., Geletkanycz, M. A., \& Sanders, W. G. (2004). Upper echelons research revisited: Antecedents, elements and consequences of top management team composition. Journal of Management, 30, 749-778.

Carpenter, M. A., \& Wade, J. B. (2002). Microlevel opportunity structures as determinants of nonCEO executive pay. Academy of Management Journal, 45, 1085-1103.

Chaganti, R., \& Sambharya, R. (1987). Strategic orientation and characteristics of upper management. Strategic Management Journal, 8, 393-401.

Cohen, S. G., \& Bailey, D. E. (1997). What makes teams work: Group effectiveness research from the shop floor to the executive suite. Journal of Management, 23, 239-290.

Collins, J. M. (1990). A market performance comparison of U.S. firms active in domestic, developed and developing countries. Journal of International Business Studies, 2, 271-287.

Damanpour, F. (1996). Organizational complexity and innovation: Developing and testing multiple contingency models. Management Science, 42, 693-716.

Das, T. K., \& Teng, B. S. (1999). Cognitive biases and strategic decision processes: An integrative perspective. Journal of Management Studies, 36, 757-778. 
Denis, D. J., Denis, D. K., \& Yost, K. (2002). Global diversification, industrial diversification, and firm value. Journal of Finance, 57, 1951-1980.

Dess, G. G., \& Beard, D. W. (1984). Dimensions of organizational task environments. Administrative Science Quarterly, 29, 52-73.

Dezsö, C. L., \& Ross, D. G. (2012). Does female representation in top management improve firm performance? A panel data investigation. Strategic Management Journal, 33, 1072-1089.

Edwards, J. R., (2008). The person-environment fit in organizations: An assessment of theoretical progress. Academy of Management Annals, 2, 167-230.

Farkas, L. (2017). Data collection in the field of ethnicity. Luxembourg: Publications Office of the European Union.

Finkelstein, S., Hambrick, D. C., \& Cannella, A. A. Jr. (2009). Strategic leadership: Theory and research on executives, top management teams, and boards. New York, NY: Oxford University Press.

Georgakakis, D., Greve, P., \& Ruigrok, W. (2017). Top management team faultlines and firm performance: Examining the CEO-TMT interface. The Leadership Quarterly, 28, 741-758.

Georgakakis, D., \& Ruigrok, W. (2017). CEO succession origin and firm performance: A multilevel study. Journal of Management Studies, 54, 58-87.

Ghemawat, P., \& Vantrappen, H. (2015). How global is your C-suite? Sloan Management Review, 56(4), 72-82.

Greve, P., Biemann, T., \& Ruigrok, W. (2015). Foreign executive appointments: A multilevel examination. Journal of World Business, 50, 674-686.

Grossman, W. (2007). Intra-industry succession, competitive dynamics, and firm performance: Through the knowledge transfer lens. Journal of Managerial Issues, 54, 340-361.

Guest, D. E., Michie, J., Conway, N. and Sheehan, M. (2003). Human resource management and corporate performance in the UK. British Journal of Industrial Relations, 41, 291-314.

Guthrie, J.P., \& Datta, D.K. (1997). Contextual influences on executive selection: Firm characteristics and CEO experience. Journal of Management Studies, 34, 537-560.

Haleblian, J., \& Finkelstein, S. (1993). Top management team size, CEO dominance, and firm performance: The moderating roles of environmental turbulence and discretion. Academy of Management Journal, 36, 844-863.

Hambrick, D. C. (2007). Upper echelons theory: An update. Academy of Management Review, 32, 334-343 
Hambrick, D. C., Finkelstein, S., \& Mooney, A. (2005). Executives sometimes lose it, just like the rest of us. Academy of Management Review, 30, 503-508.

Hambrick, D. C., \& Fukutomi, G. D. (1991). The seasons of a CEO's tenure. Academy of Management Review, 16, 719-742.

Hambrick, D. C., \& Mason, P. (1984). Upper echelons: The organization as a reflection of its top managers. Academy of Management Journal, 15, 514-535.

Harrison, D. A., \& Klein, K. J. (2007). What's the difference? Diversity constructs as separation, variety or disparity in organizations. Academy of Management Review, 32, 1199-1228.

Harvey, S., Currall, S., \& Hammer, T. (2017). Decision diversion in diverse teams: Findings from inside a corporate boardroom. Academy of Management Discoveries, 3, 358-381.

Heckman, J. (1979). Sample selection bias as a specification error. Econometrica, 47, 153-161.

Heyden, M.L.M., van Doorn, S., Reimer, M., van den Bosch, F., Volberda, H. (2013). Perceived environmental dynamism, relative competitive performance, and top management team heterogeneity: Examining correlates of upper echelons' advice seeking. Organization Studies, 34: 1327-1356.

Heyden, M.L.M., Reimer, M., \& van Doorn, S. (2017). Innovating beyond the horizon: CEO career horizon, top management team composition, and R\&D intensity. Human Resource Management, $56,205-224$.

Heyden, M.L.M., Sidhu, J., \& Volberda, H., (2015). The conjoint influence of top and middle management characteristics on management innovation. Journal of Management, 44, 1505-1529.

Hill, C. W., \& Hoskisson, R. E. (1987). Strategy and structure in the multiproduct firm. Academy of Management Review, 12, 331-341.

Hollenbeck, G.P. (2009). Executive selection - what's right... and what's wrong. Industrial and Organizational Psychology, 2, 130-143.

Hutzschenreuter, T., \& Horstkotte, J. (2013). Performance effects of top management team demographic faultlines in the process of product diversification. Strategic Management Journal, 34: 704-726.

Jackson, S. E., Joshi, A., \& Erhardt, N. L. (2003). Recent research on team and organizational diversity: SWOT analysis and implications. Journal of Management, 29, 801-830.

Jackson, S., Stone, V., \& Alvarez, E. (1993). Socialization amidst diversity: The impact of demographics on work team oldtimers and newcomers. In L. L. Cummings \& B. M. Staw (Eds.), Research in organizational behavior, vol. 15: 45-109. Greenwich, CT: JAI Press.

Johnson, G. (1988). Rethinking incrementalism. Strategic Management Journal, 9, 75-91. 
Kanter, R. M. (1977). Men and women of the corporation. New York, NY: Basic Books.

Karaevli, A., \& Zajac, E. J. (2013). When do outsider CEOs generate strategic change? The enabling role of corporate stability. Journal of Management Studies, 50, 1267-1294.

Keck, S. L., \& Tushman, M. L. (1993). Environmental and organizational context and executive team structure. Academy of Management Journal, 36, 1314-1344.

Klimoski, R. J., \& Koles, K. L. K. (2001). The chief executive officer and top management team interface. In Zaccaro, S. J. \& Klimoski, R. J. (Eds.), The Nature of Organizational Leadership: 219-269. San Francisco, CA: Jossey-Bass.

Krause, R. (2017). Being the CEO's boss: An examination of board chair orientations. Strategic Management Journal, 38, 697-713.

Kristof, A.L., (1996). Person-organization fit: An integrative review and its conceptualizations, measurement and implications. Personnel Psychology, 49, 1-49.

Kristof-Brown, A. L., Zimmerman, R. D., \& Johnson, E. C. (2005). Consequences of individuals' fit at work: A meta-analysis of person-job, person-organization, person-group, and

person-supervisor fit. Personnel Psychology, 58, 281-342.

Kristof-Brown, A. L., \& Guay, R. P. (2011). Person-environment fit. In S. Zedeck (Ed.), American Psychological Association Handbook of Industrial and Organizational Psychology (Vol. 3, pp. 350). Washington DC: American Psychological Association.

Latham, G. P., Wexley, K. N., \& Pursell, E. D. (1975). Training managers to minimize rating errors in the observation of behavior. Journal of Applied Psychology, 60, 550-555.

Li, J. \& Hambrick, D. C., (2005). Factional groups: A new vantage on demographic faultlines, conflict, and disintegration in work teams. Academy of Management Journal, 48, 794-813.

McPherson, M., Smith-Lovin, L., \& Cook, J. M. (2001). Birds of a feather: Homophily in social networks. Annual Review of Sociology, 27, 415-444.

Miller, D., (1987). Strategy making and structure: Analysis and implications for performance. Academy of Management Journal, 30, 7-32.

Milliken, F. J., \& Martins, L. L. (1996). Searching for common threads: Understanding the multiple effects of diversity in organizational groups. Academy of Management Review, 21, 402-433.

Naveen, L., (2006). Organizational complexity and succession planning. Journal of Financial and Qualitative Analysis, 41: 661-683.

Nielsen, S. (2009). Why do top management teams look the way they do? A multilevel exploration of the antecedents of TMT heterogeneity. Strategic Organization, 7, 277-305. 
Nielsen, B. B., \& Nielsen, S. (2013). Top management team nationality diversity and firm performance: A multilevel study. Strategic Management Journal, 34, 373-382.

Oehmichen, J., Heyden, M., Georgakakis, D., \& Volberda, H. (2017). Boards of directors and organizational ambidexterity in knowledge intensive firms. International Journal of Human Resource Management, 28: 283-306.

Ou, A. Y., Seo, J., Choi, D., \& Hom, P. W. (2017). When can humble top executives retain middle managers? The moderating role of top management team faultlines. Academy of Management Journal, 60, 1915-1931.

Pelled, L. H., Eisenhardt, K. M., \& Xin, K. R. (1999). Exploring the black box: An analysis of work group diversity, conflict and performance. Administrative Science Quarterly, 44, 1-28.

Pennings, J. M., \& Wezel, F. C. (2010). Faraway, yet so close: Organizations in demographic flux. Organization Science, 21, 451-468.

Petersen, T., \& Saporta, I. (2004). The opportunity structure for discrimination. American Journal of Sociology, 109, 852-901.

Phillips, K. W., Liljenquist, K. A., \& Neale, M. A. (2009). Is the pain worth the gain? The advantages and liabilities of agreeing with socially distinct newcomers. Personality and Social Psychology Bulletin, 35, 336-350.

Quigley, T. J., \& Hambrick, D. C. (2012). When the former CEO stays on as board chair: Effects on successor discretion, strategic change, and performance. Strategic Management Journal, 33, 834-859.

Raudenbush, S. W., \& Bryk, A. S. (2002). Hierarchical linear models: Applications and data analysis methods. Newbury Park, CA: Sage.

Richard, O. (2000). Racial diversity, business strategy, and firm performance: A resource based view. Academy of Management Journal, 43, 164-177.

Richard, O. C., Shelor R. (2002). Linking top management team age heterogeneity to firm performance: Juxtaposing two mid-range theories. International Journal of Human Resource Management, 13, 958-974.

Roberto, M.A. (2003). The stable core and dynamic periphery in top management teams. Management Decision, 41, 120-131.

Ruigrok, W., \& Greve, P. (2008). The rise of an international market for executive labour. In L. Oxelheim \& C. Wihlborg (Eds.), Markets and compensation for executives in Europe (pp. 53-78). Bingley, UK: Emerald

Schaubroeck, J., Ganster, D. C., \& Jones, J. (1998). Organization and occupation influences in the attraction-selection-attrition process. Journal of Applied Psychology, 83, 869-891. 
Schaubroeck, J., \& Lam, S. S. K. (2002). Dispositional similarity, group homogeneity and organizational advancement in different cultures. Academy of Management Journal, 45, 11201136.

Schneider, B. (1987). The people make the place. Personnel Psychology, 40, 437-453.

Semadeni, M., Withers, M. C., \& Certo, S. T. (2014). The perils of endogeneity and instrumental variables in strategy research: Understanding through simulations. Strategic Management Journal, 35, 1070-1079.

Seong, J., Kristof-Brown A., Park, W., Hong, D., \& Shin, Y. (2015). Person-Group fit: Diversity antecedents, proximal outcomes, and performance at the group level. Journal of Management, 41, 1184-1213.

Shen, W., \& Cannella, A. A. Jr. (2002). Revisiting the performance consequences of CEO succession: The impact on successor type, post succession senior executive turnover, and departing CEO tenure. Academy of Management Journal, 45, 717-733.

Shore, L. M., Randel, A. E., Chung, B. G., Dean, M. A., Ehrhart, K. H., \& Singh, G. (2011). Inclusion and diversity in work groups: A review and model for future research. Journal of Management, 37, 1262-1289.

Tajfel, H. (1974). Social identity and intergroup behaviour. Social Science Information, 13, 65-93.

Tallman, S., \& Li, J. (1996). Effects of international diversity and product diversity on the performance of multinational firms. Academy of Management Journal, 39, 179-196.

Thompson, J. D. (1967). Organizations in action. New York: McGraw-Hill.

Tihanyi, L., Ellstrand, A. E., Daily, C. M., \& Dalton, D. R. (2000). Composition of the top management team and firm international diversification. Journal of Management, 26, 1157-1177.

Tsui, A.S. , Egan, T.D. \& O'Reilly, C.A. III. (1992). Being different: Relational demography and organizational attachment. Administrative Science Quarterly, 37, 549-579.

Tuggle, C., Schnatterly, K., \& Johnson, R. (2010). Attention patterns in the boardroom: How board composition and processes affect discussion to entrepreneurial issues. Academy of Management Journal, 53, 550-571.

Van Knippenberg, D., De Dreu, C. K. W., \& Homan, A. C. (2004). Work group diversity and group performance: An integrative model and research agenda. Journal of Applied Psychology, 89: 10081022.

Van Veen, K., \& Marsman, I. (2008). How international are executive boards of European MNCs? Nationality diversity in 15 European countries. European Management Journal, 26, 188-198. 
Werbel, J.D., \& Johnson, D.J. (2001). The use of person-group fit for employment selection: A Missing link in person-environment fit. Human Resource Management, 40, 227-240.

Weng, D. H., \& Lin, Z. J. (2014). Beyond CEO tenure: The effect of CEO newness on strategic changes. Journal of Management, 40, 2009-2032.

Westphal, J. D., \& Zajac, E. J. (1995). Who shall govern? CEO/board power, demographic similarity, and new director selection. Administrative Science Quarterly, 40, 60-83.

Weick, K. E. (1979). The social psychology of organizing. Reading, MA: Addison Wesley.

Wiersema, M. F., \& Bantel, K. (1992). Top management team demography and corporate strategic change. Strategic Management Journal, 35, 91-121.

Williams, K. Y., \& O'Reilly III, C. A. (1998). Demography and diversity in organizations: A review of 40 years of research. Research in Organizational Behavior, 20, 77-140.

Zajac, E. J. \& Westphal, J. D. (1996). Who shall succeed? How CEO/board preferences and power affect the choice of new CEOs. Academy of Management Journal, 39, 64-90.

Zhang, Y., \& Rajagopalan, N. (2004). When the known devil is better than an unknown god: An empirical study of the antecedences and consequences of relay CEO successions. Academy of Management Journal, 47, 483-500.

Zhang, Y. (2008). Information asymmetry and the dismissal of newly appointed CEOs: An empirical investigation. Strategic Management Journal, 29, 859-872.

Zhang, Y. \& Qu, H. (2016). The impact of CEO succession with gender change on firm performance and successor early departure: Evidence from China's publicly listed companies 1997-2010. Academy of Management Journal, 59: 1845-1868. 
Table 1. Correlation Matrix

\begin{tabular}{|c|c|c|c|c|c|c|c|c|c|c|c|c|c|}
\hline Variables & Mean & S.D. & 1 & 2 & 3 & 4 & 5 & 6 & 7 & 8 & 9 & 10 & 11 \\
\hline $\begin{array}{l}\text { 1.Demographic } \\
\text { dissimilarity }\end{array}$ & 1.04 & 0.43 & $\sim$ & & & & & & & & & & \\
\hline $\begin{array}{l}\text { 2.External } \\
\text { appointment (yes=1) }\end{array}$ & 0.38 & 0.49 & $-0.08 *$ & $\sim$ & & & & & & & & & \\
\hline 3.Advanced education & 0.75 & 0.43 & -0.01 & -0.01 & $\sim$ & & & & & & & & \\
\hline $\begin{array}{l}\text { 4. CEO } \\
\text { firm tenure }(\log )\end{array}$ & 2.19 & 0.99 & 0.02 & $-0.20 *$ & 0.04 & $\sim$ & & & & & & & \\
\hline $\begin{array}{l}\text { 5.Admin.complexity } \\
\text { (employees log) }\end{array}$ & 10.00 & 1.62 & $0.12 *$ & $-0.20^{*}$ & -0.03 & $0.30 *$ & $\sim$ & & & & & & \\
\hline 6. DOI & 0.64 & 0.31 & $0.24 *$ & $-0.11 *$ & $0.10^{*}$ & $0.13^{*}$ & $0.25^{*}$ & $\sim$ & & & & & \\
\hline $\begin{array}{l}\text { 7.IncumbentTMT } \\
\text { social diversity }\end{array}$ & 0.71 & 0.32 & $0.47 *$ & 0.04 & 0.03 & 0.01 & 0.06 & $0.29 *$ & $\sim$ & & & & \\
\hline $\begin{array}{l}\text { 8.Incumbent TMT } \\
\text { functional diversity }\end{array}$ & 0.60 & 0.18 & 0.03 & 0.06 & 0.03 & $0.11^{*}$ & -0.05 & $0.15^{*}$ & $0.15^{*}$ & $\sim$ & & & \\
\hline 9. $\log$ Team size & 1.93 & 0.36 & $0.28 *$ & $-0.08 *$ & -0.05 & 0.03 & $0.27 *$ & $0.23 *$ & $0.31 *$ & $0.37 *$ & $\sim$ & & \\
\hline 10. Past performance & 0.04 & 0.05 & $0.13 *$ & -0.01 & -0.01 & $0.13 *$ & $-0.14 *$ & $0.20 *$ & $0.10^{*}$ & $0.18^{*}$ & 0.01 & $\sim$ & \\
\hline $\begin{array}{l}\text { 11.Environmental } \\
\text { uncertainty }\end{array}$ & 0.01 & 0.02 & -0.00 & -0.00 & -0.03 & $-0.10^{*}$ & $-0.15^{*}$ & -0.03 & -0.08 & $0.08 *$ & 0.04 & 0.04 & $\sim$ \\
\hline
\end{tabular}


Table 2. Variance Decomposition

\begin{tabular}{|l|l|}
\hline Null model & $\begin{array}{l}\text { Variance decomposition } \\
\text { (percentage) }\end{array}$ \\
\hline Level 1 (individual) & 0.47 \\
\hline Level 2 (firm) & 0.42 \\
\hline Level 3 (industry) & 0.11 \\
\hline Deviance: $-2 *$ e(11) & 496.23 \\
\hline Significance & $\mathrm{p}<0.001$ \\
\hline
\end{tabular}


Table 3. HLM Analysis Predicting Dissimilarity of New Executives a, b

\begin{tabular}{|c|c|c|c|c|c|}
\hline & Model 1 & Model 2 & Model 3 & Model 4 & Model 5 \\
\hline & coef. & coef. & coef. & coef. & coef. \\
\hline Intercept & $\begin{array}{l}1.11 * * * \\
(0.18)\end{array}$ & $\begin{array}{l}1.15^{* * *} \\
(0.18)\end{array}$ & $\begin{array}{l}1.18^{* * * *} \\
(0.18)\end{array}$ & $\begin{array}{l}1.16^{* * * *} \\
(0.18)\end{array}$ & $\begin{array}{l}1.18^{* * * *} \\
(0.18)\end{array}$ \\
\hline $\begin{array}{l}\text { Inverse Mill's } \\
\text { ratio }\end{array}$ & $\begin{array}{l}0.07 \\
(0.08)\end{array}$ & $\begin{array}{l}0.06 \\
(0.08)\end{array}$ & $\begin{array}{l}0.06 \\
(0.08)\end{array}$ & $\begin{array}{l}0.06 \\
(0.08)\end{array}$ & $\begin{array}{l}0.06 \\
(0.08)\end{array}$ \\
\hline $\begin{array}{l}\text { Year dummies } \\
\text { Country dummies } \\
\text { Level } \mathbf{3} \\
\end{array}$ & $\begin{array}{l}\text { included } \\
\text { included }\end{array}$ & $\begin{array}{l}\text { included } \\
\text { included }\end{array}$ & $\begin{array}{l}\text { Included } \\
\text { Included }\end{array}$ & $\begin{array}{l}\text { Included } \\
\text { Included }\end{array}$ & $\begin{array}{l}\text { included } \\
\text { included }\end{array}$ \\
\hline $\begin{array}{l}\text { Environmental } \\
\text { uncertainty } \\
\text { Level } 2\end{array}$ & $\begin{array}{l}0.58 \\
(0.82)\end{array}$ & $\begin{array}{l}0.50 \\
(0.82)\end{array}$ & $\begin{array}{l}0.41 \\
(0.81)\end{array}$ & $\begin{array}{l}1.81 \dagger \\
(0.97)\end{array}$ & $\begin{array}{l}1.55 \\
(0.97)\end{array}$ \\
\hline Team size $(\log )$ & $\begin{array}{l}0.21 * * \\
(0.07)\end{array}$ & $\begin{array}{l}0.19 * * \\
(0.07)\end{array}$ & $\begin{array}{l}0.21 * * \\
(0.07)\end{array}$ & $\begin{array}{l}0.19 * * \\
(0.07)\end{array}$ & $\begin{array}{l}0.21 * * \\
(0.07)\end{array}$ \\
\hline $\begin{array}{l}\text { Incumbent TMT } \\
\text { social diversity }\end{array}$ & $\begin{array}{l}0.33 * * * \\
(0.06)\end{array}$ & $\begin{array}{l}0.34 * * * \\
(0.06)\end{array}$ & $\begin{array}{l}0.33 * * * \\
(0.06)\end{array}$ & $\begin{array}{l}0.34 * * * \\
(0.06)\end{array}$ & $\begin{array}{l}0.33 * * * \\
(0.06)\end{array}$ \\
\hline $\begin{array}{l}\text { Incumbent TMT } \\
\text { functional diversity }\end{array}$ & $\begin{array}{l}-0.23 * \\
(0.11)\end{array}$ & $\begin{array}{l}-0.20 \dagger \\
(0.11)\end{array}$ & $\begin{array}{l}-0.21 \dagger \\
(0.11)\end{array}$ & $\begin{array}{l}-0.19 \dagger \\
(0.11)\end{array}$ & $\begin{array}{l}-0.20 \dagger \\
(0.11)\end{array}$ \\
\hline Past performance & $\begin{array}{l}0.95 * * \\
(0.36)\end{array}$ & $\begin{array}{l}0.95 * * \\
(0.35)\end{array}$ & $\begin{array}{l}1.03 * * \\
(0.35)\end{array}$ & $\begin{array}{l}0.97 * * \\
(0.35)\end{array}$ & $\begin{array}{l}1.03 * * \\
(0.35)\end{array}$ \\
\hline $\begin{array}{l}\text { Administrative } \\
\text { complexity } \\
\text { (employees log) }\end{array}$ & $\begin{array}{l}0.02 \\
(0.02)\end{array}$ & $\begin{array}{l}0.02 \\
(0.02)\end{array}$ & $\begin{array}{l}0.00 \\
(0.02)\end{array}$ & $\begin{array}{l}0.02 \\
(0.02)\end{array}$ & $\begin{array}{l}0.01 \\
(0.02)\end{array}$ \\
\hline DOI & $\begin{array}{l}0.11 \\
(0.08)\end{array}$ & $\begin{array}{l}0.10 \\
(0.08)\end{array}$ & $\begin{array}{l}0.10 \\
(0.08)\end{array}$ & $\begin{array}{l}0.11 \\
(0.08)\end{array}$ & $\begin{array}{l}0.11 \\
(0.08)\end{array}$ \\
\hline $\begin{array}{l}\text { CEO } \\
\text { firm tenure }(\log )\end{array}$ & $\begin{array}{l}-0.02 \\
(0.02)\end{array}$ & $\begin{array}{l}-0.02 \\
(0.02)\end{array}$ & $\begin{array}{l}-0.02 \\
(0.02)\end{array}$ & $\begin{array}{l}-0.02 \\
(0.02)\end{array}$ & $\begin{array}{l}-0.02 \\
(0.02)\end{array}$ \\
\hline \multicolumn{6}{|l|}{$\underline{\text { Level } 1}$} \\
\hline $\begin{array}{l}\text { Advanced } \\
\text { education }\end{array}$ & $\begin{array}{l}0.05 \\
(0.03)\end{array}$ & $\begin{array}{l}0.05 \\
(0.03)\end{array}$ & $\begin{array}{l}0.05 \\
(0.03)\end{array}$ & $\begin{array}{l}0.05 \\
(0.03)\end{array}$ & $\begin{array}{l}0.05 \\
(0.03)\end{array}$ \\
\hline $\begin{array}{l}\text { External } \\
\text { appointment }\end{array}$ & & $\begin{array}{l}-0.08 * * \\
(0.03)\end{array}$ & $\begin{array}{l}-0.08 * * \\
(0.03)\end{array}$ & $\begin{array}{l}-0.08^{* *} \\
(0.03)\end{array}$ & $\begin{array}{l}-0.08 * * \\
(0.03)\end{array}$ \\
\hline \multicolumn{6}{|l|}{$\frac{\text { Cross-level }}{\text { interactions }}$} \\
\hline $\begin{array}{l}\text { Adm.. complexity X } \\
\text { External } \\
\text { appointment } \\
\text { Env. uncertainty X } \\
\text { External } \\
\text { appointment }\end{array}$ & & & $\begin{array}{l}0.04 * \\
(0.02)\end{array}$ & $\begin{array}{l}-3.60^{*} \\
(1.47)\end{array}$ & $\begin{array}{l}-3.11 * \\
(1.48)\end{array}$ \\
\hline Deviance: $-2 * \mathrm{e}(11)$ & $395.47 * * *$ & $388.37 * * *$ & $383.10 * * *$ & $382.40 * * *$ & $378.72 * * *$ \\
\hline
\end{tabular}


Figure 1. Effects of the interaction between external hiring and organizational complexity

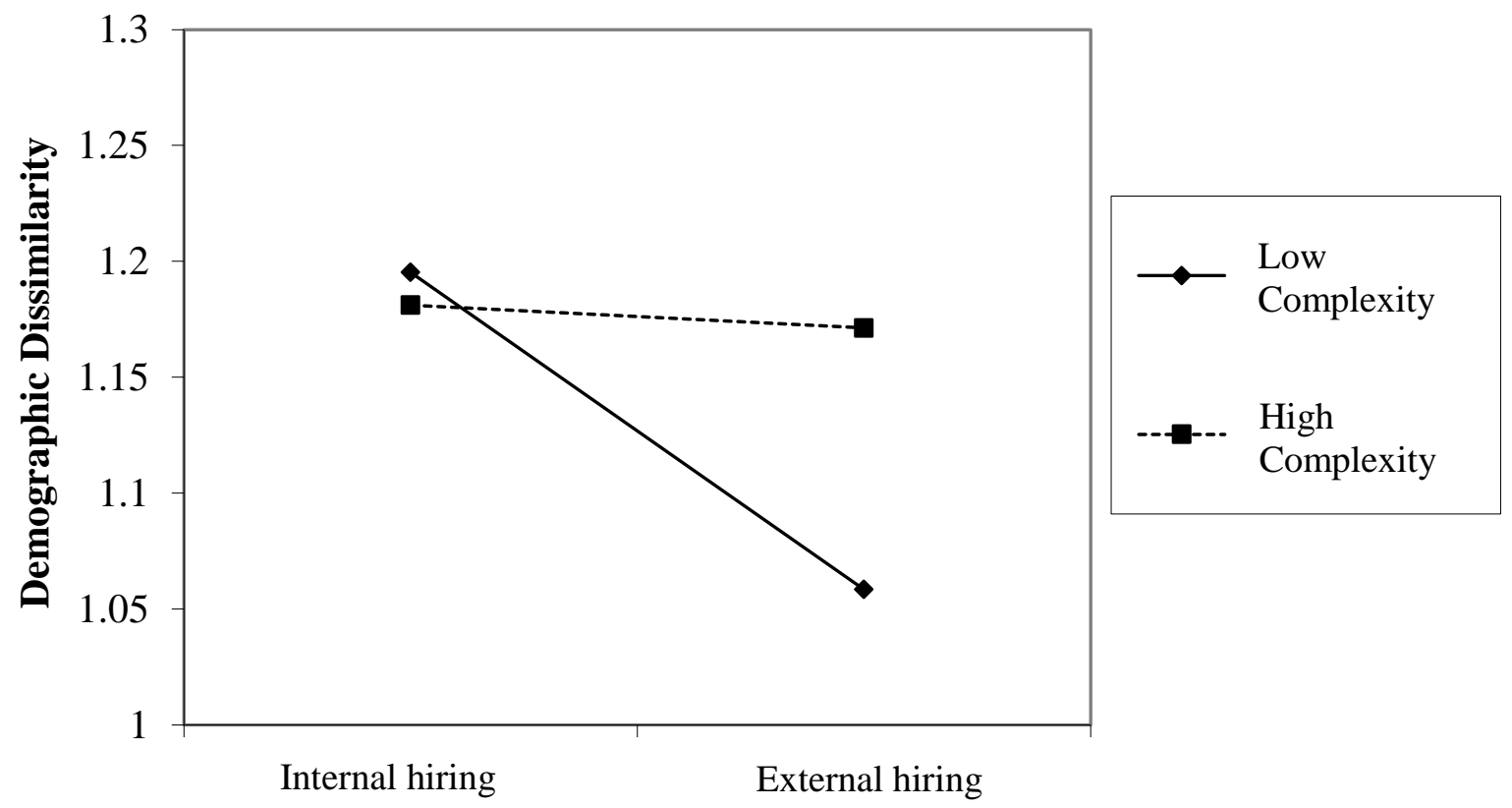

Figure 2. Effects of the interaction between external hiring and environmental uncertainty

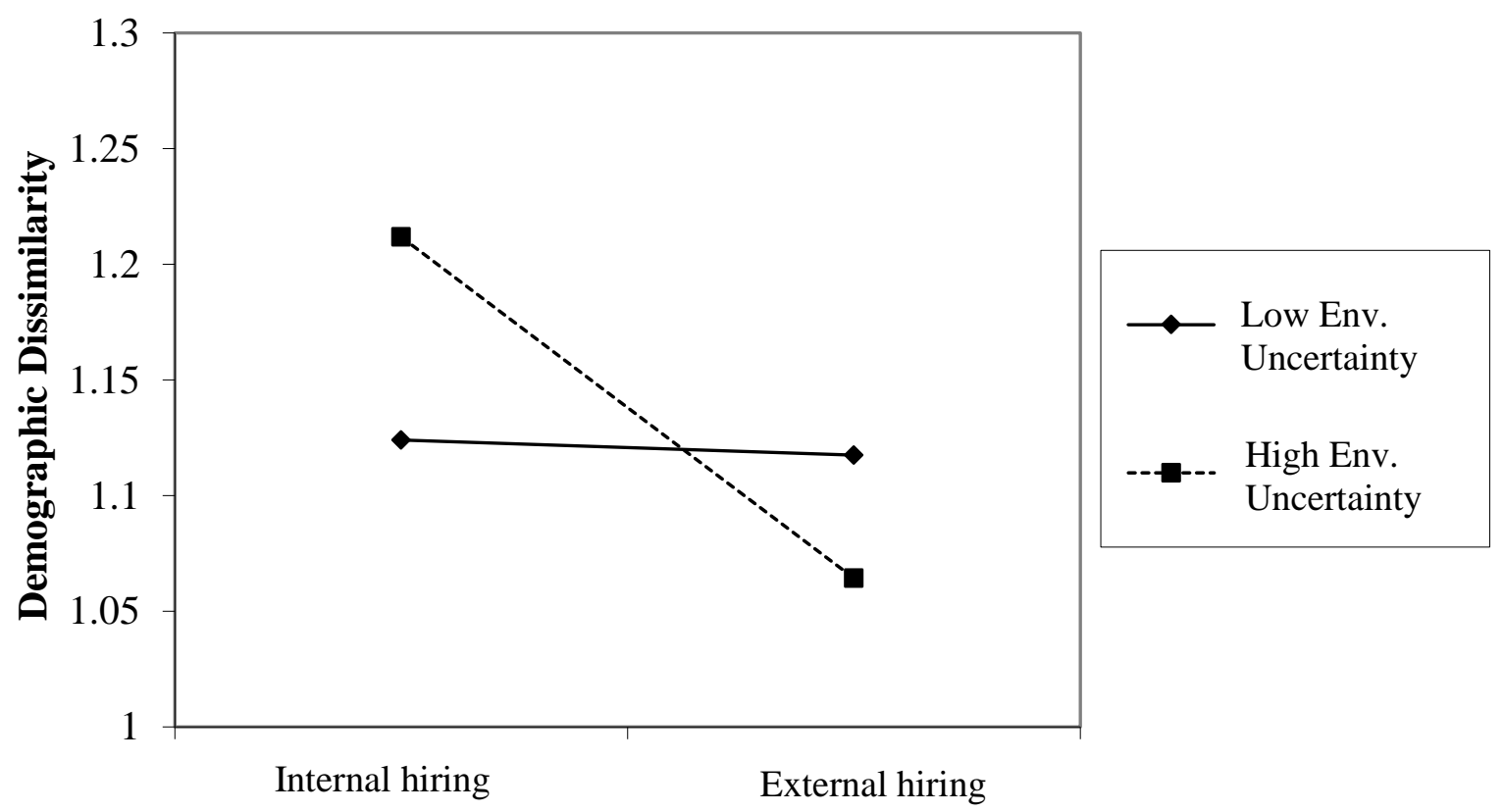




\section{Appendix}

Step 1: Probit Model of External Hiring

Coef. $\quad \underline{\text { Std.Err }}$

Intercept

$-1.73 * * *(0.14)$

Team size

$0.01 \quad(0.01)$

Past performance

$-0.70 \dagger \quad(0.41)$

Firm size (employees) $\quad-0.00 * * \quad(0.00)$

DOI $\quad-0.00 \quad(0.08)$

CEO tenure $\quad-0.04 * * *(0.01)$

Environmental uncertainty 0.43

Year $2005 \quad-0.05 \quad(0.09)$

Year $2006 \quad 0.04 \quad(0.09)$

Year 2007 omitted omitted

$\begin{array}{lll}\text { Year } 2008 & 0.02 \quad(0.09)\end{array}$

$\begin{array}{lll}\text { Year } 2009 & 0.05 & (0.09)\end{array}$

$\begin{array}{lll}\text { CHE } & -0.07 & (0.10)\end{array}$

DEU $\quad-0.08 \quad(0.10)$

NLD omitted omitted

$\begin{array}{lll}\text { GBR } & -0.01 \quad(0.11)\end{array}$

Industry external hiring rate $6.55 * * * \quad(0.85)$

$\mathrm{Chi}^{2} \quad 114.24 * * *$
$\mathrm{~N}=5365$
$\dagger \mathrm{p}<0.1, * \mathrm{p}<0.05, * * \mathrm{p}<0.01, * * * \mathrm{p}<0.001$

